TARNOWSKIE STUDIA TEOLOGICZNE 34 (2015) NR 2, S. 147-149

http://dx.doi.org/10.15633/tst.1644

ks. Andrzej Sułek

UNIWERSYTET PAPIESKI JANA PAWŁA II W KRAKOWIE

\title{
Sprawozdanie z XII naukowej konferencji katechetycznej: „Dysfunkcjonalność rodziny a działania pastoralne Kościoła” Tarnów, 13 maja 2015 roku
}

13 maja 2015 roku w Tarnowie miała miejsce kolejna, XII ogólnopolska naukowa konferencja katechetyczna „Dysfunkcjonalność rodziny a działania pastoralne Kościoła”, zorganizowana przez pracowników katedry nauk pedagogiczno-katechetycznych Wydziału Teologicznego Sekcja w Tarnowie Uniwersytetu Papieskiego Jana Pawła II w Krakowie. W budynku Wyższego Seminarium Duchownego, w auli św. papieża Jana xxıII licznie zgromadzeni uczestnicy ( $w$ większości studenci, absolwenci i doktoranci WTST UPJPII oraz nauczyciele i inni zainteresowani) mogli wysłuchać interesujących wystąpień i wziąć udział w dyskusji wokół poruszanej problematyki. Konferencję otwarła modlitwa w intencji rodziców i innych osób znaczących w życiu ludzi. Dziekan wTst ks. dr hab. Janusz Królikowski, prof. UPJPII witając prelegentów i wszystkich obecnych, zaakcentował trafność i aktualność tematyki rodziny w aspekcie rozmaitych dysfunkcji, a gratulując organizatorom, a szczególnie ks. prof. zw. dr. hab. Józefowi Stali, głównemu organizatorowi konferencji, wyraził radość, że konferencja podejmuje nowe zagadnienia $\mathrm{w}$ odniesieniu do Pana Boga, co pozwala spojrzeć na rodzinę z Bożej perspektywy i ubogacić uczestników nie tylko intelektualnie, ale i duchowo.

Autor pierwszego wystąpienia Rodzina zdrowa a rodzina dysfunkcjonal$n a$, ks. prof. zw. dr hab. Józef Stala, prorektor UPJPII, przybliżył tematykę konferencji, wyjaśniając pojęcie rodziny dysfunkcjonalnej, w której zaburzenia struktur, relacji i ról rodzinnych pociągają za sobą zakłócenia w wystarczająco dobrym wypełnianiu swojej funkcji przez rodzinę i jej członków (osłabianie, minimalizowanie, ograniczanie, nadmierna koncentracja na sobie, niezdolność do wyrażania uczuć, skłonność do przemocy). Prelegent zauważył, że odchodzenie przez rodzinę od tradycyjnego systemu wartości odbija się niekorzystnie na warunkach rozwoju osobistego dzieci, 
na zmniejszaniu poczucia odpowiedzialności rodziców za wychowanie, co pomnaża liczbę rodzin dysfunkcjonalnych. Taka rodzina stając się coraz bardziej bezradna, samotna i podatna na rozpad wymaga zewnętrznej pomocy duchowej, moralnej, psychicznej i materialnej.

Drugi referat, Wsparcie rodziny w procesie wychowania, wygłosiła dr hab. Elżbieta Osewska, pracownik naukowo-dydaktyczny i profesor nadzwyczajny Uniwersytetu Kardynała Stefana Wyszyńskiego w Warszawie, członek Międzynarodowej Polskiej Komisji Akredytacyjnej. Autorka akcentowała, że na rodzinę wpływa dziś wiele czynników zewnętrznych (polityka światowa, państwo, polityka społeczna, a zwłaszcza rodzinna, media). Wskazała też przemiany, jakim ulega polska rodzina (wzrost wieku osób zawierających małżeństwo, zmniejszająca się dzietność, rozwody powodujące coraz większą liczbę rodzin zrekonstruowanych i tzw. „patchworkowych”, w których żyją byli małżonkowie, ich obecni partnerzy oraz dzieci z tych związków). Mocną i szczęśliwą rodzinę charakteryzują mocne więzi, miłość, akceptacja, szacunek, przyjęcie na siebie zobowiązań, poświęcanie sobie nawzajem czasu, docenianie innych, prawidłowa komunikacja interpersonalna, wiara i przekonania, umiejętność radzenia sobie w sytuacji kryzysu. Rodzinę wspiera szkoła i Kościół, ale od Kościoła rodzina oczekuje nie tylko wsparcia duchowego i sakramentalnego, ale też konkretnej pomocy w rozwiązywaniu problemów egzystencjalnych i wychowaniu dzieci. Prelegentka wyraziła postulat bardziej realnego patrzenia przez wspólnoty parafialne na sytuację rodzin i podejmowania prób ich wspierania.

Ks. dr hab. Jacek Siewiora, pracownik naukowo-dydaktyczny i profesor nadzwyczajny Małopolskiej Wyższej szkoły Ekonomicznej w Tarnowie przedstawił referat Zaburzenia funkcji opiekuńczej/kulturowej rodziny a duszpasterstwo. Autor, wymieniając funkcje rodziny (prokreacyjną, socjalizacyjną, wychowawczą), analizuje też funkcję opiekuńczą, która realizuje się poprzez sprawowanie opieki i polega na zaspokajaniu potrzeb ponadpodmiotowych (tzn. takich, których jednostka nie jest w stanie sama zaspokoić). Taką funkcją jest funkcja kulturowa, która realizuje się poprzez udostępnianie członkom rodziny dorobku kulturowego i tradycji oraz czynienie go dobrem wspólnym (kierunek dośrodkowy), a także wprowadzenie jednostki w kulturę regionalną, narodową i światową (kierunek odśrodkowy). Zaburzenie tej funkcji rodziny pociąga za sobą zaburzenie relacji interpersonalnych.

Wystąpienie ks. mgr. Piotra Grzanki, zastępcy dyrektora Caritas Diecezji Tarnowskiej nosiło tytuł Działania Caritas na rzecz rodziny z zaburzeniami 
funkcjonowania. Wymieniając formy tej pomocy, prelegent podkreślił wielki wkład pracy wolontariuszy (ok. 4 tys. wolontariuszy w parafialnych oddziałach Caritas i ok. 3 tys. młodzieży w 170 szkolnych kołach Caritas), wymienił rozliczne formy pomocy rodzinom w trudnej sytuacji materialnej, zwłaszcza w następstwie klęsk żywiołowych, wskazał na znaczenie dofinansowania wakacyjnego wypoczynku dla dzieci, a także uzmysłowił słuchaczom, jak wielką pomocą dla rodzin jest objęcie specjalistyczną opieką osób znajdujących się w szczególnych sytuacjach życiowych (świetlice Lumen w Tarnowie, Mielcu i Dębicy, Dom dla Bezdomnych Mężczyzn w Tarnowie, Stacja Opieki Caritas w Tarnowie, Hospicjum i Dom Pomocy Społecznej w Dąbrowie Tarnowskiej, Dom Emerytów - Placówka Pielęgnacyjno-Opiekuńcza w Tarnowie i Zakład Opiekuńczo-Leczniczy w Grybowie oraz „okna życia” w Tarnowie i Nowym Sączu, Ośrodek Opiekuńczo-Rehabilitacyjny dla Dzieci i Młodzieży Niepełnosprawnej w Jadownikach Mokrych z różnymi jednostkami organizacyjnymi, jak np. Dom Pomocy Społecznej dla Dzieci i Młodzieży Niepełnosprawnej Intelektualnie i Ośrodek Interwencji Kryzysowej).

Kolejny prelegent, ks. dr Andrzej Sułek, pracownik naukowo-dydaktyczny UPJPII w Krakowie, wygłosił referat Rodzina dysfunkcyjna - wsparcie pastoralne Kościoła. Autor odwołał się najpierw do głosu Kościoła na rzecz rodziny dysfunkcyjnej (Jan Paweł II, Franciszek, Episkopat Polski), a następnie wskazał realizowane zwłaszcza w diecezji tarnowskiej praktyczne formy pomocy Kościoła w odniesieniu do rodziny dysfunkcyjnej. Ponieważ człowiek jest jednością psychofizycznoduchową, stąd i pomoc Kościoła osobom i rodzinom musi uwzględniać trzy sfery: fizyczną (pomoc materialna, medyczna), psychiczną (poradnictwo, terapia, interwencja kryzysowa) i duchową (kierownictwo, poradnictwo). Wymienił różnorakie przykłady pomagania rodzinom dysfunkcyjnym przez różne podmioty (instytucje kościelne, ruchy, stowarzyszenia, organizacje i inicjatywy kościelne lub wspierane przez Kościół oraz duszpasterzy i inne osoby zaangażowane w pomoc).

Po wystąpieniach nastąpiła dyskusja panelowa $\mathrm{z}$ udziałem prelegentów, którym uczestnicy stawiali pytania, a po dyskusji, prowadzący ją ks. prof. Józef Stala podsumował konferencję, potwierdzając aktualność i wagę omawianych tematów, a także zasadność poświęcenia konferencji zaproponowanemu zagadnieniu, zwłaszcza że przy obecnie obserwowanym zmasowanym ataku na rodzinę potrzeba wspólnego i kompleksowego działania różnych podmiotów na rzecz rodziny i niesienia jej pomocy. 